Кузора Игорь Евгеньевич, к.т.н., зам. начальника Испытательного центра - управления контроля качества по новым технологиям, AO «Ангарская нефтехимическая компания», e-mail: KuzoralE@anhk.rosneft.ru

Симонова Елена Валерьевна, инженер-лаборант ИЦ-УКК, АО «Ангарская нефтехимическая компания», e-mail: SimonovaEVa@anhk.rosneft.ru

\title{
ИССЛЕДОВАНИЕ СОСТАВА НЕФТЕСОДЕРЖАЩИХ ОТХОДОВ
}

Kuzora I.E., Simonova E.V. STUDY OF THE COMPOSITION OF OIL-CONTAINING WASTE

\begin{abstract}
Аннотация. Проведена инвентаризация источников образования нефтесодержащих отходов. Изучены физико-химические и химмотологические характеристики нефтешламов различной технологической природы для определения оптимальных условий переработки.

Ключевые слова: нефтешлам, нефттесодержащие отходы, источники загрязнения, утилизация.

Abstract. An inventory of sources of oily waste was conducted. The physicochemical and chemotological characteristics of sludge of various technological nature were obtained to determine the optimal processing conditions.
\end{abstract}

Keywords: oil sludge, oily waste, pollution sources, utilization.

Деятельность любого нефтеперерабатывающего предприятия неизбежно связана с техногенным воздействием на окружающую среду. Проблема влияния предприятий нефтеперерабатывающей отрасли на состояние водной экосистемы, атмосфрерного воздуха, почвы носит многоплановый характер. Наиболее опасными загрязнителями природной среды являются нефттесодержащие отходы - нефтешламы.

В настоящее время на нефтеперерабатывающих заводах России ежегодно накапливается до 600 тысяч тонн нефтешламов [1]. Нефттесодержащие отходы условно можно разделить на три группы: нефтешламы очистных coоpужений, возобновляемые и невозобновляемые, накопленные в ходе деятельности предприятий. В целом, они представляют собой густую вязкую пастообразную массу разной степени пластичности, достаточно сильно обводненную (содержание воды колеблется в широких пределах и достигает до $70 \%$ масс.). Содержание нефтепродуктов в нефтешламах изменяется в интервале 10$90 \%$ масс., механических примесей в виде абразивной или металлической пыли, песка - 0,1-45 \% масс. (таблица). Химический состав нефтешламов зависит от его происхождения, специсики производства. Процентное соотношение составляющих любого нефтешлама всегда варьируется в широких пределах.

В ходе исследований определено, что в нефтешламах, образующихся при хранении сырой нефти в резервуарах (донные отложения), содержится большое количество углеводородной части, что подчеркивает необходимость их возврата в ресурсооборот. Характеристика нефтешламов водоочистных со- 
оружений показывает, что, в первую очередь, необходимо исследовать возможность применения и переработки нефтешламов данного типа в процессах и продуктах, где не предъявляются жесткие требования по содержанию воды, механических примесей.

Таблица

Состав нефтешламов

\begin{tabular}{|l|c|c|c|}
\hline \multicolumn{1}{|c|}{ Образец } & $\begin{array}{c}\text { Водная } \\
\text { фаза, } \\
\% \text { масс. }\end{array}$ & $\begin{array}{c}\text { Твердая } \\
\text { фаза, } \\
\% \text { масс. }\end{array}$ & $\begin{array}{c}\text { Органическая } \\
\text { фаза, } \\
\% \text { масс. }\end{array}$ \\
\hline Невозобновляемые (шламонакопители) & $10-20$ & до 50 & $10-25$ \\
\hline Нефтешлам очистных сооружений & $25-70$ & $10-30$ & $20-58$ \\
\hline \multicolumn{4}{|c|}{ Донные отложения резервуаров } \\
\hline Нефтяные резервуары & до 10 & $0,1-3,0$ & $60-89$ \\
\hline Мазутные резервуары & до 20 & $0,1-10,0$ & $50-84$ \\
\hline
\end{tabular}

На основании комплексных физико-химических исследований установлено, что нефтешламы из шламонакопителей содержат в своём составе углеводородную часть, представляющую собой в основном тяжелые фрракции нефти. По составу и свойствам органическая часть нефтешлама приближена к тяжелым нефтяным остаткам. Оценивая содержание основных групп углеводородов в органической части нефтешламов, видно, что для нее характерно повышенное содержание смол и асфальтенов, тяжелых ароматических и парафиновых углеводородов, высокая плотность, что является следствием воздействия на нефтешламы климатических фракторов. Установлено, что в процессе длительного хранения происходит изменение фракционного состава углеводородной части нефтешлама - уменьшается содержание легколетучих фракций и увеличивается содержание высококипящих фракций из-за образования сложных молекул с высоким содержанием смолисто-асфальтеновых групп.

Таким образом, анализ полученных данных показывает, что нефтесодержащие отходы требуют индивидуального подхода при выборе технологий переработки, а необходимость решения проблемы утилизации нефтесодержащих отходов обусловлено не только их нарастающим количеством, но и возможностью рационального использования в качестве ценного вторичного сырья.

\section{ЛИТЕРАТУРА}

1. Гарабаджиу А.В., Сыроежко А.М., Флисюк О.М., Ицкович В.А., Пименов Ю.А., Дронов С.В., Харитонов С.В., Зайченко Л.П., Герасимов А.М., Гаврилов А.Н. Кластер технологических установок переработки многотоннажных накоплений кислых гудронов и нефтешламов // Нефтепереработка и нефтехимия. 2012. №9. С. 37-47. 